\title{
Determinants of Households' Willingness to Pay for Soil Conservation Practices: The Case of Assosa District, Assosa Zone, Benishangul Gumuz Regional State, Ethiopia
}

\author{
Zerihun Bekele \\ Department of Agricultural Economics, Selale University, Fitche, Ethiopia
}

Email address:

zer.bek78@gmail.com

To cite this article:

Zerihun Bekele. Determinants of Households' Willingness to Pay for Soil Conservation Practices: The Case of Assosa District, Assosa Zone, Benishangul Gumuz Regional State, Ethiopia. Science Research. Vol. 9, No. 1, 2021, pp. 14-20. doi: 10.11648/j.sr.20210901.13

Received: January 30, 2021; Accepted: March 10, 2021; Published: March 22, 2021

\begin{abstract}
The use of natural resources dictates economic growth in many developing economies. Unfortunately, soil erosion is on the higher side. As a result, it was important to recognize rural households' preferences for soil conservation and restoration practices. It resulted in the loss in quality and the service provided by the environment. Thus, sustainable undertaking of conservation practices is important to alleviate the problem that requires further investment. This article examined determinants of the readiness of individual homes to pay for soil preservation practices. Multi-stage random sampling was used to select from five kebeles 120 household heads. For these purposes, both primary and secondary data have been used. The primary data were gathered using a structured questionnaire from 120 sample homes. Using descriptive and inferential statistics and Tobit model, the information gathered were evaluated. The tobit model outcome showed that family gender, household head origin, household head academic level, property holding, TLU and farm earnings were positively and substantially linked to the likelihood of readiness to pay while age and original offer were negative and substantially linked to the likelihood of readiness to pay. Therefore, when developing soil preservation policies in the region, these factors should be regarded.
\end{abstract}

Keywords: Tobit Model, Maximum Willingness to Pay, Initial Bid

\section{Introduction}

More than any other continent, Africa's economic development is reliant on the growth of the agricultural and agricultural-industry sectors, which are primarily influenced by land resource productivity. This is particularly true in SubSaharan Africa, where agriculture account for the vast majority of the country's GDP and contributes the majority of its income and employment [18]. Thus, agriculture and natural resource, land, is inseparable in less developed country.

Ethiopia, as a developing nation, has depended heavily on its natural resource base in recent years. Low productivity and a rapidly declining natural resource base dominate Ethiopian agriculture, yielding national food self-sufficiency difficult. [12]. It is impossible to escape from exploitation of natural resource base to secure food and for livelihood existence in a sustainable manner.
In Ethiopia, land is an integral part of natural resource that, in addition to its economic benefits, is used to build the wellbeing of society. Maintaining long-term food production requires careful planning of this economic good. Given the fact that land provides a source of income for the vast majority of the population, land resources are deteriorating due to the removal of top fertile soil [25]. In least developed countries, where agriculture is the mainstay of the economy, soil erosion and subsequent land depletion continue to be a major environmental threat [10]. Soil degradation is one of the major contributors to the declining production and productivity.

Soil is the most significant resource on which farmers are based on sustainable farming and livelihood. Sustainable use through proper planning and designing this precious resource is therefore essential to maintaining the farm households' long-term farm productivity. Farm households are likely to account for approximately a quarter of the world's 
population, with the large percentage of them living in the worlds less developed nations. [13].

Soil degradation can occur naturally or as a result of human activity. [4] Soil depletion was divided into three categories: soil erosion, soil infertility, and soil contamination from spilled soil and industrial waste. When forest cover is removed, pastures are overgrazed, and overall land use practices are unsustainable, soil erosion is increased. Lowered fallow periods and the transition from traditional bush fallowing to permanent cultivation, induced by population pressure and agricultural activities, are prolonging this phenomenon in Nigeria and other African countries [3]. The use of inputs such as fertilizer/manuring, water conservation, and tillage methods to improve the declined agricultural productivity is serve as a measure of loss due to soil degradation [23]. Because of changing human needs and competition for various land uses, a comprehensive land use and soil conservation approach is needed. In affirmation, Yohanna et al. [27] Suggested that, a soil that has been degraded required fallowing and soil conservation activities for effective rehabilitation. Corroborating this fact, Panda, 2007 [24] emphasized that soil conservation remains the only proven method to sustain the productivity of agricultural land.

To address the problem of soil erosion and its linkage to agricultural productivity and food security, there is a need to take broader perspective, both in how the problem is defined and in the set of possible solution considered. This means that in addition to technical solution, a research is needed to identify the socio-economic factors that affect farmers' willingness to pay for soil conservation practices. Given this fact, local people contribution in the designing and preparation of conservation plan is imperative. This study was undertaken in Assosa Woreda, Benishangul Gumuz Regional State. At present the study area is faced with extreme soil erosion due to in appropriate farming practices coupled with cultivation and overgrazing of hillsides and steep slopes, changing pastureland into cropland and clearing of indigenous trees like bamboo. Ideally, this land should be returned to permanent vegetation cover and hence, improving land use through conservation practice is important. Therefore, the main objective of this study was to explore determinants of willingness to pay to stop or reduce the negative effects of soil erosion in the study area.

\section{Research Methodology}

\subsection{Description of the Study Area}

This study was conducted in Assosa Woreda, which is found in Assosa zone of the Benishangul Gumuz Regional State. There are 7 Woreda in Assosa administrative zone and Assosa Woreda is one of the 7 Woreda of Assosa administrative zones [6]. At present, the Woreda is divided into 78 Kebeles out of which 22 Kebeles are occupied by natives and 56 Kebeles are occupied by settler people.

Assosa District falls between $9^{\circ} 17^{\prime}$ and $12^{\circ} 06^{\prime}$ North, $34^{\circ}$ $10^{\prime}$ and $37^{\circ} 04^{\prime}$ East Longitude. Assosa is specifically located around $690 \mathrm{~km}$ south west direction from Addis Ababa. It covers an approximate area of $1991.41 \mathrm{sq} . \mathrm{km}$, the land use area of the district is covered by: cultivated land which comprises 18,422 ha $(9.25 \%)$, forests which comprise 285 ha (0.14\%), dense bamboo 28,047ha (14.08\%), open bamboo 6687ha $(3.36 \%)$, woodland 69,513 ha $(34.9 \%)$, shrub land 81309 ha $(40.8 \%)$ grass land 839 ha $(0.42 \%)$. The rest is covered by swampy areas 432 ha $(0.22 \%)$, water bodies 28 ha $(0.014 \%)$, and rocks and bare land 1991 ha $(0.99 \%)$. The average cultivated land holding is about 0.9 ha per household [6].

Agro-ecology of the woreda is mostly classified as subhumid lowland (Kola) and has an altitude range of 15001700 m.a.s.l. It has mono- modal rainfall pattern commencing from end of April and staying up to end of October. The average annual rainfall is around $1275 \mathrm{~mm}$ [6]. The annual min-max temperature ranges from $28^{\circ} \mathrm{C}-35^{\circ} \mathrm{C}$. The hottest period extends from January to May, the peak being March whereas the coolest periods occur from June to November, the lowest being August [5].

According to a report by CSA, the total population of the district is 145,732 [11]. Of this total population, 112,648 or $32.18 \%$ of its population are urban dwellers and the rest 237,438 or $67.82 \%$ are rural dwellers population. The population density of the region is about 73.19 people per sq. $\mathrm{km}\left(\mathrm{km}^{2}\right)$. Especially Assosa Woreda is the most densely populated Woreda in the region with a population density of 41 persons per $\mathrm{km} 2$. That means it has $2,317 \mathrm{~km}$ areas with a population of 94,698 persons. It covers an approximate area of 1991.41 sq. $\mathrm{km}$, with a population of 145,732 people of whom $75780(52 \%)$ are male and $69952(48 \%)$ are female and annual population growth rate of $2.6 \%$.

\subsection{Methods of Data Collection}

For this analysis, we gathered both primary and secondary data. Primary data was gathered from sample households in the study region using a structured questionnaire and face-toface interviews. The questionnaire was designed to collect important information related to demographic, social, institutional, economic, awareness, and soil degradation, its severity, and farmers' willingness to pay (participate in) for conservation practices through trained enumerators. The data were collected by six experienced and competent enumerators and the researcher.

Secondary data were also collected from different sources such as records, regulations, rules, reports etc. of both governmental and nongovernmental organizations which are working on soil conservation activities. The governmental organizations which may be a source of secondary data includes Assosa Woreda Office of Agriculture (AWOA), Assosa Woreda Finance and Economy Development Office (AWFED), BGRS Bureau of Agriculture (BGRS BoA), BGRS Bureau of Finance and Economic Development (BGRS BoFED), Assosa Agricultural Research Institute, and Central Statistics Authority (CSA). 


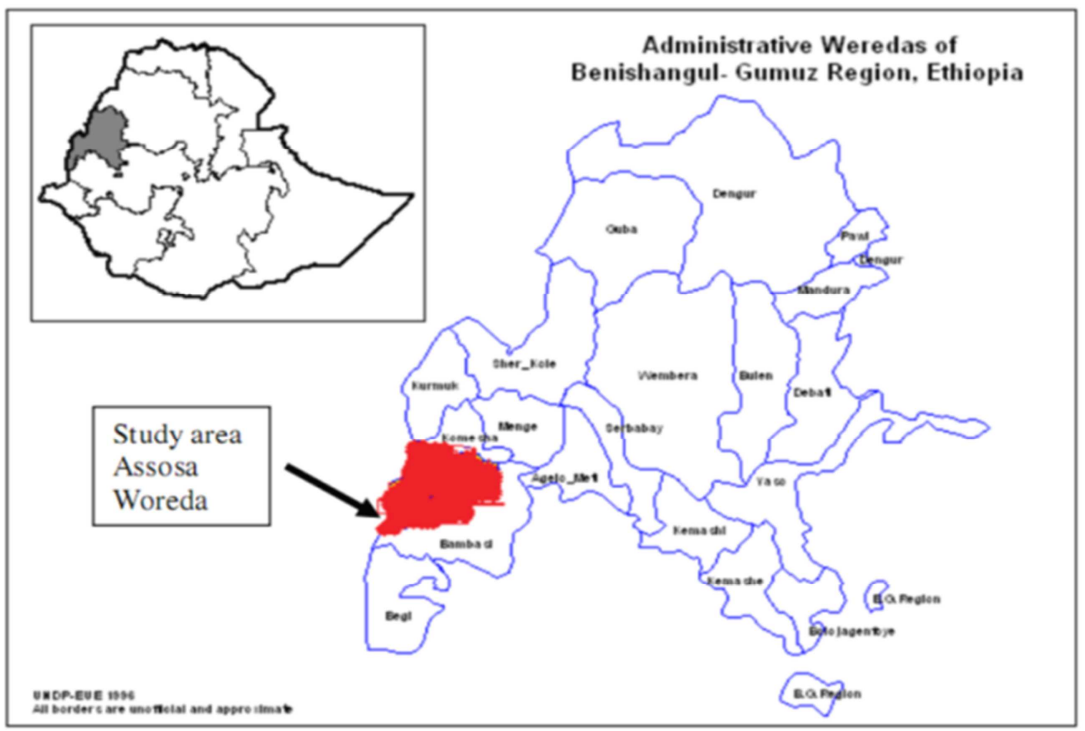

Figure 1. Map of Assosa Woreda, the study area.

\subsection{Sample Size and Sampling Technique}

A multi stage sampling technique was used to choose 120 sample households for this analysis. In the first stage, twelve of the 78 districts that contains degraded areas were purposively selected. In the second stage, the twelve districts were stratified into two groups on the basis of the origin of the households i.e. whether they are native or settlers ( 8 from settler Kebeles and 4 from native households). In the third stage, a total of five districts, two Kebeles from natives and three from settlers were randomly selected. These five sample districts were Amba 9, 7 and Megele 30 from the settler group and Tetse and Robalageda from the natives. Finally, 120 sample households were selected based on probability proportional to the number of the households in these selected districts.

Table 1. Number of sampled households taken from sample districts.

\begin{tabular}{lll}
\hline Name of Districts & Total household number & Sample size \\
\hline Amba 7 & 516 & 38 \\
Amba 9 & 370 & 27 \\
Tetse & 450 & 33 \\
Megele 30 & 180 & 13 \\
Robalageda & 108 & 9 \\
Total & 1624 & 120 \\
\hline
\end{tabular}

\subsection{Methods of Data Analysis}

\section{Specification of Econometric Model}

The Tobit model was used to investigate the determinants of WTP and the maximum amount of money a participant would be willing to pay in this analysis. This model has an advantage over other discrete models (LPM, Logistic, and Probit) in that it showed the respondents' WTP probability as well as their maximum WTP.

Following Maddala and Lahiri, 1992 [22] and Ameyan and Ogidiolu, 1989 [3] and Johnston and Dindaro, 1997 [20], the Tobit model can be defined as:

$$
M W T P^{*}=\beta_{0}+\beta^{\prime} X_{i}+\varepsilon_{i}
$$

$$
\begin{gathered}
M W T P_{i}=M W T P_{i}^{*} \text { if } M W T P_{i}^{*} \neq 0 \\
=0 \text { if } M W T P_{i}^{*} \leq 0
\end{gathered}
$$

Where:

$M W T P_{i}=$ the observed dependent variable, in this case maximum willingness to pay of each respondent.

$M W T P_{i}^{*}=$ Is a latent variable which is not observed when it is less than or equal to zero but is observed if it is greater than zero.

$X_{i}=$ Vector of factors affecting WTP

$\beta^{\prime}=$ Vector of unknown parameters

$\varepsilon_{i}=$ Error term that is independently and normally distributed with mean zero and common variance $\boldsymbol{\delta}^{2}$.

In the above model, the threshold value is zero. Since the threshold value may be set to zero or presumed to be any known or unknown value, this isn't a very strict assumption. [16]. The Tobit model shown above is also called a censored regression because it is possible to view the problem as one where observation of $M W T P_{i}^{*}$ at or below zero are censored $[19,16]$.

Maddala and Lahiri [22] and Ameyan and Ogidiolu [3] estimated the model parameters by maximizing the Tobit likelihood function of the following form.

$$
L=\prod_{M W T P_{i}^{*}>0} \frac{1}{\delta} f\left(\frac{M W T P_{i}-\beta^{\prime} X_{i}}{\delta}\right) \prod_{M W T P_{i}^{*} \leq 0} F\left(\frac{-\beta^{\prime} X_{i}}{\delta}\right)
$$

Where: $\mathrm{f}$ and $\mathrm{F}$ are respectively, the density function and cumulative distribution function of $Y_{i}^{*}$.

$\prod M W T P_{i}^{*} \leq 0$ is means the product over those $\mathrm{i}$ for which $M W T P_{i}^{*} \leq 0$, and

$\prod M W T P_{i}^{*}>0$ is means the product over those $\mathrm{i}$ for which $M W T P_{i}^{*}>0$.

The Tobit coefficients do not directly give the marginal effects of the associated independent variables on the dependent variable. But their signs show the direction of change in probability of WTP and the intensity of maximum WTP as the respective explanatory variable changes [3].

According to Scott long (1997) [21], McDonald and 
Moffit, to decompose the effect of explanatory variables into the probability of WTP and the intensity of WTP effects, the methods described could be used. Thus a change in $\mathrm{X}_{\mathrm{i}}$ (explanatory variable) has two effects: it affects conditional mean of the MWTP $^{*}$ in the positive part of the distribution and it affects the probability that the observation will fall in that part of the distribution. This decomposition approach was used in this study.

The marginal effect of an explanatory variable on the expected value of the dependent variable is:

$$
\frac{\partial E\left(M W T P_{i}\right)}{\partial X_{i}}=F(z) \beta^{\prime}
$$

Where, $\frac{\beta^{\prime} X_{i}}{\delta}$ is denoted by $\mathrm{z}$, following Maddala, (1997)

The effect of a given explanatory variable on the probability of WTP is:

\section{Result and Discussion}

\subsection{Descriptive Statistics}

Table 2. Descriptive statistics of continuous explanatory variables.

\begin{tabular}{|c|c|c|c|c|}
\hline Variable & Mean & Std. dev. & Min. & Max \\
\hline Age & 45.87 & 14.32 & 22 & 78 \\
\hline Education & 4.4 & 3.49 & 0 & 12 \\
\hline Family size & 4.79 & 2.82 & 1 & 17 \\
\hline Freq. of ext. contact & 4.8 & 4 & 0 & 12 \\
\hline Off farm income & 2045.46 & 4861.42 & 0 & 4300 \\
\hline Agricultural income & 4121.7 & 3837.65 & 192 & 10120 \\
\hline Dependency ratio & .384 & 47 & 0 & 3 \\
\hline
\end{tabular}

Source: Own survey, 2014

\subsection{Econometric Model Output}

Table 3. Tobit model estimates of WTP for soil conservation practices.

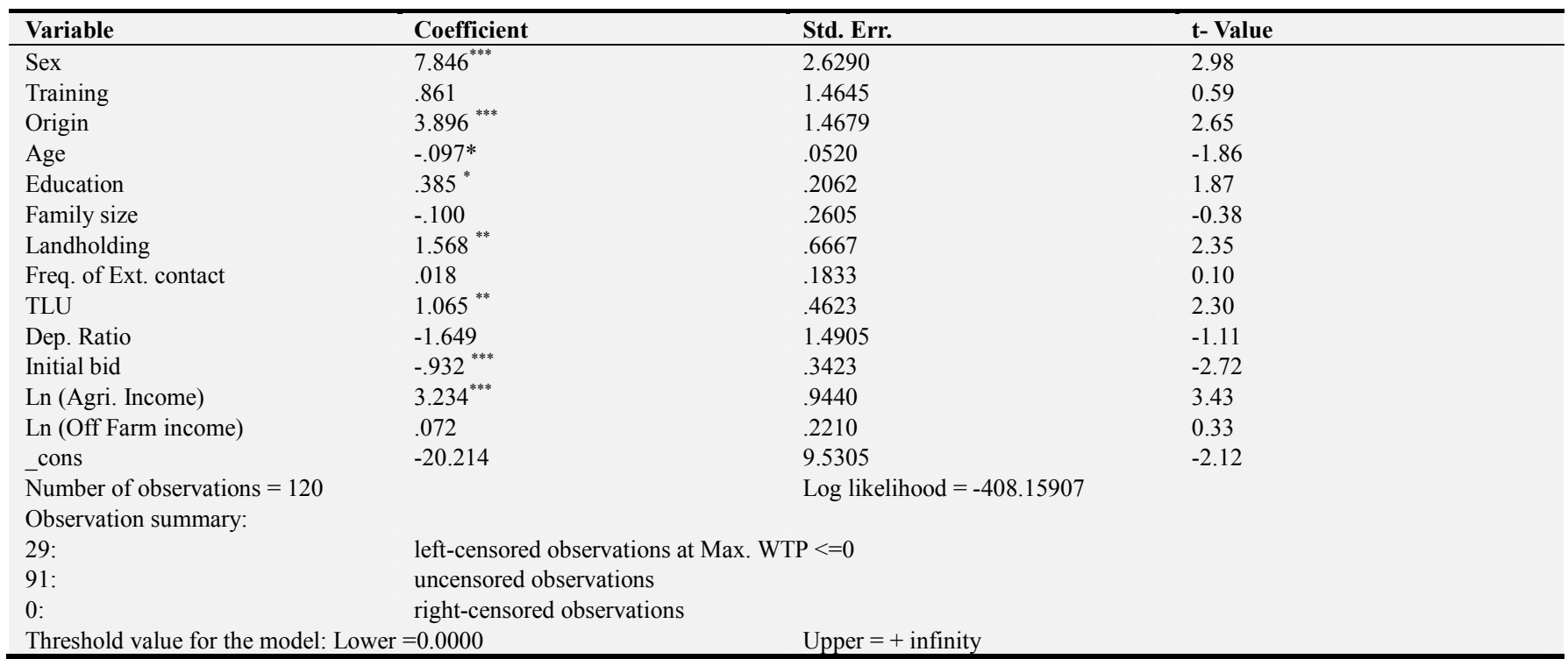

$* * *, * *, *$ significant at $1 \%, 5 \%$, and $10 \%$, level of significance respectively

Source: Own survey, 2014 
Table 4. Marginal effect of explanatory variables on the amounts of willingness to pay.

\begin{tabular}{llll}
\hline Variables & Changes in probabilities of WTP & $\begin{array}{l}\text { changes among the willing } \\
\text { household }\end{array}$ & $\begin{array}{l}\text { changes among the whole } \\
\text { population }\end{array}$ \\
\hline Sex* & .3100 & 4.6744 & 6.2599 \\
Training* & .0226 & .6109 & .7734 \\
Origin* & .1125 & 2.6806 & 3.4357 \\
Age & -.0025 & -.0689 & -.0870 \\
Education & .0099 & .2751 & .3473 \\
Family Size & -.0026 & -.0715 & -.0902 \\
Landholding & .0404 & 1.1188 & 1.4125 \\
Fre. of Ext. Contact & .0005 & .0130 & .0164 \\
TLU & .0275 & .7599 & .9594 \\
Dependency Ratio & -.0425 & -1.1767 & -1.4856 \\
Initial Bid & -.0240 & -.6654 & -.8401 \\
Ln (Agricultural Income) & .0834 & 2.3083 & 2.9142 \\
Ln (Off Farm Income) & .0019 & .0516 & .0651 \\
\hline
\end{tabular}

$\left.{ }^{*}\right) \mathrm{dy} / \mathrm{dx}$ is for discrete change of dummy variable from 0 to 1

\subsection{Determinants of Willingness to Pay for Soil Conservation Practices}

The explanatory variables that influence households' WTP for soil conservation practices were investigated using the Tobit model. As an effect, the following are the explanatory variables that directly influence households' WTP.

Sex of the household head: The household head's sexual identity is related with his or her willingness to pay for soil and water conservation practices, and this interaction is significant at the $1 \%$ significance level. Male-headed households were found to be able to pay more for soil conservation practices than female-headed households, as per the Tobit model. [1], and [2], reported the same result. This is due to the fact that female-headed households have less resources and cultural restrictions than male-headed households. Holding all other variables stable, the marginal effect of the explanatory variable shows that male-headed households are 31 percent more likely than female-headed households to pay for soil conservation practices. Furthermore, households headed by male will pay Birr 4.67 more than households headed by female.

Origin: The result from the model also indicated that being a settler has positive relation with WTP as expected and is significant at $1 \%$. This might be because the settler households perceive the soil degradation problem as a main push factor for their migration and thus willing to contribute more than natives. But the result should be interpreted more carefully and it does not mean that the native have no concern for environmental degradation. Being a settler household increases the chances of being ready to pay for soil conservation practices by 11.25 percent, and the value they are willing to contribute increases by 2.68 Birr, as indicated by the marginal effect of the value of the variable.

Education level: At a 10\% significance level, the number of years schooling by the household head had a detrimental effect on willingness to pay. This could be because education will improve farmers' ability to obtain, process, and use knowledge. Furthermore, schooling represents gained environmental awareness. Thus, this variable positively linked with household's willingness to pay. This was consistent with the findings of Gebremariam and Edriss [14] and Asrat et al. [19]. Our findings also show that, when other variables are kept constant, each additional year of schooling increases the probability of farmers' willingness to pay by 0.9 percent. Also, as the year of schooling increased by one year, the amount of cash a household is willing is increased by Birr 0.35 among the total population and Birr 0.27 among willing households.

Age: The age of the household head variable's parameter prediction was negatively and noticeably linked to maximum willingness to pay at $10 \%$ as expected, indicating that young household heads are more willing to pay than old household heads. This may be because, due to their longer projection period, young households are also expected to take risks. Studies by Tesfaye et al. [26] and Alemayehu et al. [7] suggested similar results. The output of the Tobit model shows that a one-year rise in age reduces the probability of farmers' WTP in cash for soil conservation practice by 0.25 percent while keeping other factors constant. Similarly, if a person's age rises by a year, the amount of money he or she will pay decreases by 0.087 in the general population and 0.069 in the willing, ceteris paribus.

Agricultural income: At the 1\% significance level, a farmer's gross income from agricultural activities was found to affect willingness to pay. This finding is in accordance with basic economic theory, which notes that people's demand for most goods and services is positively linked to their income level. When all other variables are held constant, the marginal effect shows that a 1 Birr rise in agricultural income raises the probability of willingness to pay by 8.34 percent.

Land holding: This factor reflects a household's total cultivated land and is significant at the $5 \%$ probability level. The reason for this is might be households who have enough land could produce more crops and get better income. This finding is consistent with results of Haileslassie et al. [17] and Animut [2]. The marginal effect of this variable shows that a unit increase in land holding of the household increases the probability of WTP by $4 \%$. Also, farmers that have more cultivated land would pay Birr 1.12 more than those farmers that do have lesser land. 
TLU: At the 5\% significance level, livestock ownership in TLU was found to have a positive effect on the respondent's willingness to pay. The probability of WTP rises as the amount of livestock owned by farmers grows. There are two major reasons for this: In first, having more livestock means having more assets, which enhances a household's ability to make investment decisions. Second, since farmers have large livestock herds, they need more land and water to provide adequate and high-quality feeding and drinking water to their herds, which necessitates increased investment in soil conservation practices. Keeping other factors constant, the probability of being willing to pay increases by a probability of $2.75 \%$ as livestock ownership increased by 1 TLU. And also, farmers who have more livestock numbers are 0.76 Birr more willing than lower number of livestock.

Initial bid: As predicted, the coefficient of initial bid was negative and statistically significant at $1 \%$. Respondents would be less likely to consider the scenario as the bid quantity rises and that is reliable with the theory of demand. Using the marginal approach, it was found that as the starting bid price increased by one unit, the likelihood of a household's WTP for soil conservation decreased by 2.4 percent. In addition, when the starting bid price rises by one Birr, the amount of money a farmer can spend on soil conservation practices falls by 0.66 Birr.

\section{Conclusion}

For rural Ethiopian households, soil is a valuable resource. However, erosion is causing this valuable resource to deteriorate, especially in communal areas. As a result, preserving degraded lands is a critical decision that will hasten the improvement of rural farmers' livelihoods through livestock production and other means of subsistence. Thus, involving local communities in degraded areas is vital.

Conserving the soil resource is important to increase production and productivity of the agricultural sector. Sustainable conservation of resources requires active participation of the local communities from designing up to implementation phase. This study was, therefore, conducted so as to know the determinants of willingness of the community in the study area to pay for soil conservation practices.

The result from the model indicated that out of thirteen explanatory variables which were hypothesized to explain the households' WTP, eight of them were found to be significant in affecting the probability of WTP for the conservation of soil resource. Consequently, sex, origin, education level of the household head, gross income from agriculture, land holding and livestock owned were all their probability of WTP was found to be positively and significantly related those variables. The household head's age and the bid values offered were found to have a negative and significant effect on the probability of WTP for soil conservation.

Based on the outcome of the survey, it can be inferred that decision-makers and policymakers interested in valuation of conservation practices should consider the factors mentioned above when setting policy.

\section{References}

[1] Alemu Mekonnen. 2000. Valuation of community forestry in Ethiopia: A contingent valuation study of rural households. Environment and Development Economics, 5 (3): 289-308.

[2] Anemut Belete. 2006. Determinants of Farmers' Willingness to Pay for the Conservation of National Parks. The Case of Simen Mountains National Park. MSc. Thesis, University of Haramaya, Haramaya, Ethiopia.

[3] Ameyan, O. and Ogidiolu, O., 1989. Agricultural land use and soil degradation in a part of kwara state, Nigeria. Environmentalist, 9 (4), pp. 285-290.

[4] Asadu C. L. A., Ezeaku P. I. and Nnaji G. U. (2004). Land use and soil management situation in Nigeria: An analytical review of changes. Outlook on Agriculture, 33, 27-37

[5] AsARC (Assosa Agricultural Research Center). 2008. Annual report of Assosa Agricultural Research Center. Assosa, Ethiopia.

[6] AWOA (Assosa Woreda Office of Agriculture). 2013. Annual agricultural report of Assosa district. Assosa, Ethiopia.

[7] Alemayehu, B., Bogale, A., Wollny, C. and Tesfahun, G., 2010. Determinants of choice of market-oriented indigenous Horo cattle production in Dano district of western Showa, Ethiopia. Tropical animal health and production, 42 (8), pp. 1723-1729.

[8] Alemayehu, Befikadu., Hagos, Fitsum., Haileslassie, Amare., Mapedza, E., Awulachew, S. B. and Tesfaye Tafesse, D. P., 2009. Prospect of payments for environmental services in the Blue Nile Basin: examples from Koga and Gumera watersheds, Ethiopia. Improved Water and Land Management in the Ethiopian Highlands: Its Impact on Downstream Stakeholders Dependent on the Blue Nile, p. 254.

[9] Berhanu G., Gebremedhin W., Yigzaw D., Tilahun G. and Worku T., 2009. Sustainable Land Management through Market-oriented Commodity Development: Case Studies from Ethiopia. Improving Productivity and Market Success (IPMS) of Ethiopian Farmers Project, International Livestock Research Institute (ILRI), Working Paper 21, Addis Ababa, Ethiopia: 46p.

[10] Bruutrup M. and Zimmermann, R. 2009. Agriculture as the Potential Engine for African Growth and the Role of NEPAD. CESifo Forum. 29p.

[11] CSA (Central Statistical Authority), 2007. Population and housing census, Addis Ababa, Ethiopia.

[12] Eleni Alemu. 2008. Continued Use of Soil and Water Conservation Practices: a Case study in Tulla District, Ethiopia. M. Sc. Thesis, Wageningen University, Netherlands.

[13] Ellis, F., 2000. Farm Households and Agrarian Development. Cambridge University Press, Cambridge.

[14] Gebremariam, G. G. and Edriss, A. K., 2012. Valuation of soil conservation practices in Adwa Woreda, Ethiopia: A contingent valuation study. Journal of Economics and Sustainable Development, 3 (13), pp. 97-107. 
[15] Gete Z., Menale K., John Pender and Mahmud Y. 2006. Stakeholder Analysis for Sustainable Land Management (SLM) in Ethiopia: Assessment of Opportunities, Strategic Constraints, Information Needs, and Knowledge Gaps. Environmental Economics Policy Forum. 97p.

[16] Green WH (2000). Econometric Analysis. 3rd edition. Macmillan Publishing Company. New York.

[17] Haileslassie Asfaw, Fitsum Hagos and Seleshi Bekele Awulachew, Don Peden Solomon Gebreselassie, Fekahmed Negash, 2008. Indicators of Environmental Degradation in the Blue Nile Basin: Exploring Prospects for Payment for Environmental Services. Proceeding of Nile basin development forum. 16-19 November, Sudan Khartoum.

[18] Henao, J., and C. Baanante. 2006. Agricultural Production and Soil Nutrient Mining in Africa: Implications for Resource Conservation and Policy Development. Alabama: IFDC.

[19] Asrat, P., Belay, K. and Hamito, D., 2004. Determinants of farmers' willingness to pay for soil conservation practices in the southeastern highlands of Ethiopia. Land Degradation \& Development, 15 (4), pp. 423-438.

[20] Johnston P, Dindaro J (1997). Econometric Methods. 4th edition. The McGraw-Hill Companies, Inc. New York.
[21] Long, J. S. and Long, J. S., 1997. Regression models for categorical and limited dependent variables (Vol. 7). Sage.

[22] Maddala, G. S. and Lahiri, K., 1992. Introduction to econometrics (Vol. 2). New York: Macmillan.

[23] Mbagwu, J. S., 2003. Environmental control of soil structure in Mediterranean soils. Lecture given at the college on soil physics. LNS0418023, pp. 255-259.

[24] Panda, S. C., 2007. Soil water conservation and dry farming. Agrobios (India).

[25] Tekalign Molla. 2008. Opening Address to the $9^{\text {th }}$ annual Conference of the Ethiopian Society of Soil Science, April 17 2008.

[26] Tesfaye Zegeye, Bedassa Tadesse and Shiferaw Tesfaye. 2000. Determinants of high yielding maize technology adoption: empirical evidence from southwestern Oromia. EARO, Addis Ababa Ethiopia.

[27] Yohanna, J. K., Ode, S., Habiba, K. A., Usman, A. and Azagaku, E. D., 2012. Adopted engineering and agronomic conservation measures of agricultural land use in Lafia LGA Nasarawa state of Nigeria. Asian Journal of Agriculture and Rural Development, 2 (393-2016-24004), pp. 155-161. 